\title{
Morpho-anatomical traits of two lowest internodes related to lodging resistance in selected genotypes of Triticum
}

\author{
Danuta Packa, Marian Wiwart*, Elżbieta Suchowilska, and Teresa Bieńkowska \\ Department of Plant Breeding and Seed Production, University of Warmia and Mazury in Olsztyn, \\ Pl. Łódzki 3, 10-724 Olsztyn, Poland
}

Received January 7, 2015; accepted August 21, 2015

\begin{abstract}
$\mathrm{A} \mathrm{b} s \mathrm{tr}$ a c t. The cross-sections of first and second internodes were analyzed under a light and fluorescence microscopes in six varieties of Triticum spelta, two varieties of T. polonicum, and one variety of T. aestivum. The morphometric parameters of stem cross-sections were measured. The analyzed wheats were characterized by significant differences in traits associated with lodging resistance $i e$ : internode diameter, lumen diameter, stem wall thickness, mechanical layer thickness, area of transverse section, and area of lumen for the first and second internode and between the internodes. In all varieties, the values of internode diameter, lumen diameter, area of transverse section and area of lumen were higher for the second internode than for the first internode, whereas the reverse was reported for stem wall thickness and mechanical layer thickness The results of the principal component analysis and section modulus values revealed similarities between spring spelt Wirtas and Rubinas and between common wheat Kontesa and winter spelt Poeme and Epanis. The number of large vascular bundles varied across the studied varieties. The average number of vascular bundles in common wheat Kontesa was significantly higher than in spring spelt Rubinas and Wirtas and significantly lower than in Polish wheat Pol-3 and winter spelt Epanis and Poeme.

K e y w o r d s: ancient wheats, stem cross-section, microscopy, image analysis system, principal component analysis, section modulus
\end{abstract}

\section{INTRODUCTION}

Lodging of cereal crops is a serious problem in agricultural production that lowers yield, deteriorates qualitative parameters, and obstructs mechanical harvesting. Lodging is defined as irreversible buckling of plant stems away from the vertical position (Pinthus, 1973). Three types of lodging are defined in the literature: root lodging caused by

*Corresponding author e-mail: marian.wiwart@uwm.edu.pl weak root structure, stem lodging caused by buckling of lower internodes due to differences in weight and strength between the upper and lower internodes of the stem, buckling of the middle internodes, commonly known as brackling, and buckling of the peduncle directly below the ear, commonly referred to as necking (Berry et al., 2004; Ruebenbauer, 1964). The negative effects of lodging are enhanced by environmental factors such as heavy rainfall, strong winds, inadequate fertilization, and pest invasions. Lodging creates unfavourable conditions for growth by limiting light and air access, obstructing assimilation and respiration, and contributing to proliferation of pathogens. The above factors lower the quantity and quality of cereal crops and make harvest more difficult (Berry et al., 2004; Pinthus, 1973).

Resistance to lodging is a hereditary and varietal trait that is determined by morphological, anatomical, physiological, and chemical parameters of stems and roots. In plant breeding, attempts are made to identify traits correlated with lodging resistance. The identified characteristics can be used in the process of selecting resistant genotypes. Plant height is most highly correlated with lodging, but other parameters are also analyzed, including the number, length, and thickness of internodes, stem weight, anatomical, chemical, and mechanical properties of stems, and root parameters (Berry et al., 2004; Zuber et al., 1999; Żebrowski, 1992a,b). In plant breeding, screening for resistance to lodging is difficult because this quantitative trait is controlled by many genes, and its expression is significantly influenced by environmental factors (Keller et al., 1999). Resistance to lodging can be determined in a variety of ways. The most 
popular method is field evaluation, which may include artificially induced lodging (eg dense sowing, excessive nitrogen fertilization, plot flooding, mechanical bending of stems). Several methods for direct determination of lodging resistance have been proposed for breeding purposes. One of them was developed in the 1950s, and it involves the determination of the lodging coefficient, namely the ratio of the second internode diameter $(\mathrm{mm})$ to stem length $(\mathrm{cm})$ (Milczarski, 2008; Ruebenbauer and Riegerowa, 1955). Scientific advancements contributed to the development of a diagnostic method based on Fourier transform infrared resonance (FTIR) and principal component analysis (PCA). This method is used to evaluate variations in the chemical composition of cell walls that determine the mechanical properties of stems (Wang et al., 2012). The correlations between various plant traits and lodging resistance have been widely studied, but an index of resistance traits that could be used in breeding programs has not yet been developed. In wheat breeding programs, plant height remains the most practical and easily selectable trait for lodging resistance (Kelbert et al., 2004a; Zuber et al., 1999). Lodging resistance should be one of the major goals of minor cereals breeding in Europe. This can be a factor which will determine the cultivation of hulled wheats in the future.

Spelt (Triticum spelta L.) is cultivated in organic farms in many European countries, including Germany, Austria, Switzerland, Belgium, Slovenia, Spain, northern Italy, and Poland (Konvalina et al., 2014; Tyburski and Babalski, 2006). In Europe, total spelt acreage is estimated at 100000 ha (Longin and Würschum, 2014), and it exceeded
1600 ha in Poland in 2010 (Cacak-Pietrzak et al., 2013). A total of 42 spelt varieties had been entered into the Common Catalogue of Varieties of Agricultural Plant Species (CCA) by 2013, including three local cultivars, for preservation of biodiversity. Lodging is one of the main causes of annual fluctuations in spelt production because old landraces and most varieties available on the market are characterized by long and weak culms and, consequently, high risk of lodging (Keller et al., 1999; Koutroubas, 2012).

Polish wheat (Triticum polonicum L.) is grown on a small scale in southern Spain, southern Italy, Algeria, Ethiopia, and warm regions of Asia. The Polish climate does not offer a supportive habitat for Polish wheat, but its various forms constitute a rich source of genetic material for breeding cultivars with high nutritional value and increased resistance to Fusarium head blight (FHB) (Wiwart et al., 2013). There is a general scarcity of published data about Polish wheat is resistance to lodging.

The objective of this study was to analyze selected morphological and anatomical traits associated with lodging resistance in T. spelta and T. polonicum and to compare them with common wheat $T$. aestivum.

\section{MATERIALS AND METHODS}

The experimental material is described in Table 1. The field experiment was established in the Experimental Centre in Bałcyny near Ostróda $\left(53^{\circ} 36^{\prime} \mathrm{N} ; 1^{\circ} 51^{\prime} \mathrm{E}\right)$. Winter varieties were sown in the autumn of 2011, and spring varieties were sown in the spring of 2012. The plot area was $6 \mathrm{~m}^{2}$. The sowing density was 220 germinating kernels per $1 \mathrm{~m}^{2}$

T a b l e 1. Description of plant material

\begin{tabular}{lll}
\hline Species & Variety & Country of origin, variety \\
T. aestivum & Kontesa & PL, spring variety \\
& POL-3 & $\begin{array}{l}\text { spring variety selected from accession NCPGR (PL 22488), reproduced in the Department of Plant } \\
\text { B. polonicum }\end{array}$ \\
& POL-5 & spring variety selected from accession NCPGR (PL 23047) and reproduced in the above Department \\
& Wirtas & $\begin{array}{l}\text { PL, spring variety developed at the University of Warmia and Mazury in Olsztyn and protected by } \\
\text { plant breeders rights* }\end{array}$ \\
& Rubinas & $\begin{array}{l}\text { PL, spring variety developed at the University of Warmia and Mazury in Olsztyn and protected by } \\
\text { provisional plant breeders rights* }\end{array}$ \\
& Epanis & BE, winter variety \\
& Poeme & BE, winter variety \\
& EP1H22 & CH, winter variety \\
& Ostro & CH, winter variety
\end{tabular}

\footnotetext{
*www.coboru.pl/Polska/Ochrona/ochrona_KO.aspx
} 
for T. polonicum and T. spelta, and 360 kernels per $1 \mathrm{~m}^{2}$ for common wheat. PK fertilizer was applied pre-sowing at a rate of $25-80 \mathrm{~kg} \mathrm{ha}^{-1}$. Nitrogen fertilizer was applied at two equal rates of $20 \mathrm{~kg} \mathrm{ha}^{-1}$ each. The first rate was applied before sowing (spring varieties) and at the beginning of the growing season (winter varieties), and the second rate towards the end of the stem elongation stage (BBCH 39) (Witzenberger et al., 1989). The seeds were not dressed, and no chemical weed control was applied during the growing season.

At the beginning of heading (BBCH 52-55), 1-cm-long stem sections were sampled from the central part of the first and second internode from five plants of each tested variety. Plant material was fixed in FAA (formalin-acetic acid-alcohol, 90:5:5 v/v) and embedded in paraffin (Gerlach, 1972; Rovenska, 1973). Paraffin blocks were sliced into 20-25 $\mu \mathrm{m}$ thick sections using a Leica RM2125 rotary microtome. Paraffin was removed and the sections were stained with $1 \%$ safranin solution (Safranin O, Sigma) in 50\% ethanol and $0.1 \%$ fast green solution (Fast Green FCF, Sigma) in absolute alcohol (Gerlach, 1972). After dehydration in isopropyl alcohol, the sections were mounted in Euparal and observed under a stereoscopic microscope (SMZ-2T Nikon) and a light and fluorescence microscope (FM - Labophot Nikon) equipped with a Nikon B-3A filter. Microphotographs were taken with the Nikon DS DS-5M Camera Head for colour and fluorescence imaging. Safranin stains lignified cell walls red, and fast green stains cellulose walls. Under the microscope, safranin-stained lignified cell walls fluoresced yellow to green, whereas cellulose walls stained with fast green were red and did not fluoresce. Microphotographs of stem cross-sections taken under a stereoscopic microscope (30x) and a light and fluorescence microscope (40x and 100x) were used to perform morphometric measurements of stem cross-sections in the ImageJ application (Rasband, 1997-2014). The following parameters were determined:

- internode diameter (ID) (mm);

- lumen diameter (LD) (mm);

- stem wall thickness (SWT) (mm);

- mechanical layer thickness (MLT) (mm);

- area of transverse section (ATS) $\left(\mathrm{mm}^{2}\right)$;

- area of the stem wall (ASW) $\left(\mathrm{mm}^{2}\right)$;

- area of lumen $(\mathrm{AL})\left(\mathrm{mm}^{2}\right)$;

- number and distribution of vascular bundles (VB).

Each variety was represented by $15-20$ cross-sections of the first and second internode.

In all analyzed varieties, the values of the section modulus $(Z)$ for two lower internodes were calculated using the formula for annular cross section (Ookawa et al., 2010; Rajput, 2012) on the theoretical assumption that a wheat stem internode has a circular tube structure:

$$
Z=\pi\left(D^{4}-d^{4}\right) / 32 D
$$

where: $D$ - internode diameter, $d$-lumen diameter.

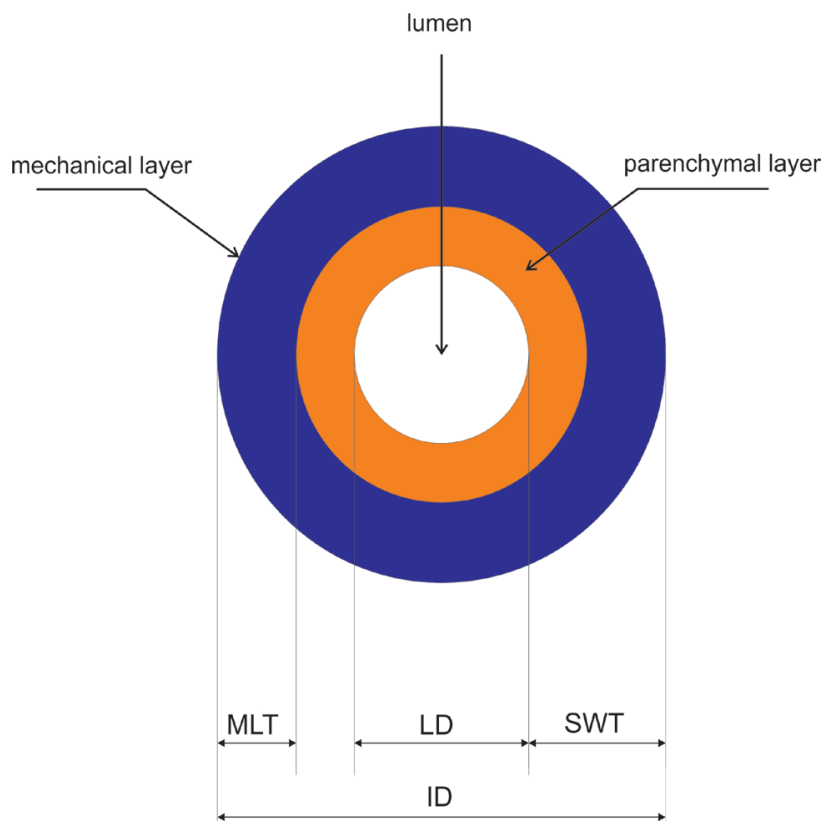

Fig. 1. Cross-section of the centre of the internode. ID - internode diameter, LD - lumen diameter, MLT - mechanical layer thickness, SWT - stem wall thickness.

The results of all analyses were processed statistically using STATISTICA v.10 software (Statsoft Inc., 2011). The significance of differences between means was estimated by analysis of variance, and mean values were compared by the multiple Student-Newman-Keuls (SNK) test. The data were subjected to principal component analysis (PCA) performed for all analyzed traits: internode diameter (ID), lumen diameter (LD), stem wall thickness (SWT), mechanical layer thickness (MLT), area of transverse section (ATS), area of lumen (AL), and area of the stem wall (ASW) (Fig. 1).

\section{RESULTS}

Common wheat Kontesa was characterized by the largest diameter of the first and second internode of 3.413 and $3.607 \mathrm{~mm}$, respectively (Table 2). The first node diameter was significantly smaller in Wirtas, Rubinas, Pol-5, and EP1H22 (2.617 to $3.124 \mathrm{~mm}$ ). In a majority of the evaluated varieties, excluding Poeme and Pol-5, the diameter of the second internode was significantly smaller than in Kontesa. Spring spelt Rubinas and Wirtas were characterized by the smallest diameters of both internodes (Fig. 2). In all analyzed wheats, the second internode diameter was larger than the first internode diameter, and the observed differences were significant in five varieties: Pol-5, Rubinas, Wirtas, Poeme, and E1PH22 (Table 2).

The stems of all analyzed wheats were hollow, and the lumen diameter (LD) varied between varieties (Table 2, Fig. 2). The first and second internode LD values were the highest in winter spelt Epanis and Ostro, the smallest first 
T a b l e 2. Morphological and anatomical traits of first and second lower internodes of the studied Triticum genotypes

\begin{tabular}{|c|c|c|c|c|c|c|c|c|}
\hline \multirow{2}{*}{ Species } & \multirow{2}{*}{ Variety } & ID & LD & SWT & MLT & ATS & $\mathrm{AL}$ & ASW \\
\hline & & \multicolumn{4}{|c|}{$(\mathrm{mm})$} & \multicolumn{3}{|c|}{$\left(\mathrm{mm}^{2}\right)$} \\
\hline \multicolumn{9}{|c|}{ 1st internode } \\
\hline T. aestivum & Kontesa & $3.413 \mathrm{a}$ & $1.200 \mathrm{ab}$ & $1.107 \mathrm{~cd}$ & $0.434 \mathrm{c}$ & $9.016 \mathrm{a}$ & $1.124 \mathrm{abc}$ & 7.891ab \\
\hline \multirow{2}{*}{ T. polonicum } & Pol-3 & $3.367 \mathrm{abc}$ & $0.755 \mathrm{c}$ & $1.306 \mathrm{~b}$ & $0.556 \mathrm{a}$ & $8.634 \mathrm{ab}$ & $0.607 \mathrm{de}$ & $8.027 \mathrm{a}$ \\
\hline & Pol-5 & $3.106 \mathrm{c}$ & $0.392 d$ & $1.524 \mathrm{a}$ & $0.543 \mathrm{a}$ & $7.526 b$ & $0.111 \mathrm{f}$ & $7.501 \mathrm{ab}$ \\
\hline \multirow{2}{*}{$\begin{array}{l}\text { T. spelta } \\
\text { (spring) }\end{array}$} & Rubinas & $2.699 d$ & $0.867 \mathrm{c}$ & $1.195 \mathrm{bc}$ & $0.409 \mathrm{c}$ & $5.727 \mathrm{c}$ & $0.566 \mathrm{de}$ & $5.525 \mathrm{c}$ \\
\hline & Wirtas & $2.617 d$ & $0.771 \mathrm{c}$ & $0.923 \mathrm{~d}$ & $0.392 \mathrm{c}$ & $5.353 \mathrm{c}$ & $0.462 \mathrm{e}$ & $4.891 \mathrm{c}$ \\
\hline \multirow{4}{*}{$\begin{array}{l}\text { T. spelta } \\
\text { (winter) }\end{array}$} & Epanis & $3.387 \mathrm{ab}$ & $1.382 \mathrm{a}$ & $1.003 \mathrm{~d}$ & $0.412 \mathrm{c}$ & $8.896 \mathrm{a}$ & $1.483 \mathrm{a}$ & $7.413 \mathrm{ab}$ \\
\hline & Poeme & $3.336 \mathrm{abc}$ & $0.976 b c$ & $1.180 \mathrm{bc}$ & $0.589 \mathrm{a}$ & $8.662 \mathrm{ab}$ & 0.772 cde & $7.890 \mathrm{ab}$ \\
\hline & EP1H22 & $3.124 b c$ & $1.132 \mathrm{ab}$ & $0.996 \mathrm{~d}$ & $0.574 a$ & $7.534 b$ & $0.956 \mathrm{~cd}$ & $6.577 b$ \\
\hline & Ostro & $3.209 \mathrm{abc}$ & $1.334 \mathrm{a}$ & $0.938 \mathrm{~d}$ & $0.487 \mathrm{~b}$ & $8.018 \mathrm{ab}$ & $1.335 \mathrm{ab}$ & $6.683 b$ \\
\hline \multicolumn{9}{|c|}{ 2nd internode } \\
\hline T. aestivum & Kontesa & $3.607 \mathrm{a}$ & $1.296 \mathrm{~cd}$ & $1.155 \mathrm{a}$ & $0.423 b c$ & $10.090 \mathrm{ab}$ & $1.518 b$ & $8.572 \mathrm{a}$ \\
\hline \multirow{2}{*}{ T. polonicum } & Pol-3 & $3.400 \mathrm{bc}$ & $1.070 \mathrm{e}$ & $1.165 \mathrm{a}$ & $0.416 b c^{* * *}$ & $8.965 d$ & $0.948 \mathrm{c}$ & $8.017 \mathrm{a}$ \\
\hline & Pol-5 & $3.542 \mathrm{ab} * * *$ & $1.359 \mathrm{bc} * * *$ & $1.091 \mathrm{ab} * * *$ & $0.442 b^{* * *}$ & $9.801 b c^{* * *}$ & $1.427 b^{* * *}$ & $8.374 \mathrm{a}$ \\
\hline \multirow{2}{*}{$\begin{array}{l}\text { T. spelta } \\
\text { (spring) }\end{array}$} & Rubinas & $2.896 \mathrm{~d}^{*}$ & $1.041 \mathrm{e}^{* *}$ & $0.927 \mathrm{~cd} * * *$ & $0.395 \mathrm{c}$ & $6.411 \mathrm{e}^{*}$ & $0.844 c^{* *}$ & $5.568 \mathrm{c}$ \\
\hline & Wirtas & $2.768 \mathrm{~d}^{*}$ & $1.134 \mathrm{de}^{* * *}$ & $0.817 \mathrm{~d}$ & $0.432 b c$ & $5.982 \mathrm{e}^{*}$ & $0.957 \mathrm{c} * * *$ & $5.025 \mathrm{c}$ \\
\hline \multirow{4}{*}{$\begin{array}{l}\text { T. spelta } \\
\text { (winter) }\end{array}$} & Epanis & $3.449 \mathrm{bc}$ & $1.674 \mathrm{a}^{* * *}$ & $0.888 \mathrm{~d}^{* * *}$ & $0.404 \mathrm{bc}$ & $9.271 \mathrm{~cd}$ & $2.166 \mathrm{a} * * *$ & $7.105 b$ \\
\hline & Poeme & $3.690 \mathrm{a}^{* * *}$ & $1.637 \mathrm{a}^{* * *}$ & $1.026 b c * *$ & $0.473 \mathrm{a}^{* * *}$ & $10.642 \mathrm{a} * * *$ & $2.020 \mathrm{a} * * *$ & $8.593 \mathrm{a}$ \\
\hline & EP1H22 & $3.345 \mathrm{c} * * *$ & $1.517 \mathrm{ab} * * *$ & $0.919 \mathrm{~cd}^{* *}$ & $0.433 b c^{* * *}$ & $8.587 d^{* *}$ & $1.788 \mathrm{ab}^{* * *}$ & $6.799 b$ \\
\hline & Ostro & $3.338 \mathrm{c}$ & $1.710 \mathrm{a}^{* * *}$ & $0.814 d^{* *}$ & $0.394 \mathrm{c}^{* * *}$ & $8.594 d$ & $2.204 \mathrm{a}^{* * *}$ & $6.391 b$ \\
\hline
\end{tabular}

ID - internode diameter, LD - lumen diameter, SWT - stem wall thickness, MLT - mechanical layer thickness, ATS - area of transverse section, AL - area of lumen, ASW - area of stem wall; a-f - means signed by the same letter differ not significantly according to SNKtest at $\mathrm{p}<0.05$, separately for the first and second internode. Difference between the first and second internode significant according to t-test at $* \mathrm{p}<0.05, * * \mathrm{p}<0.001, * * * \mathrm{p}<0.0001$. 
a

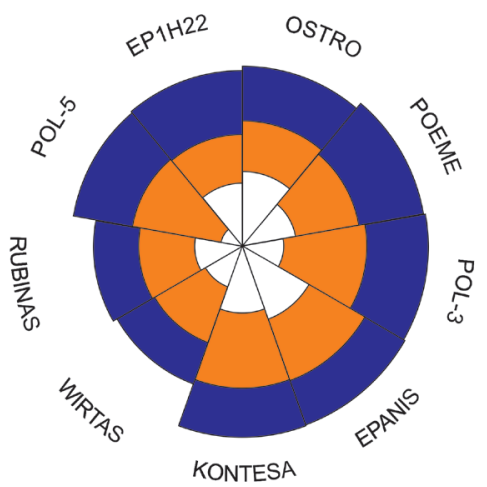

b

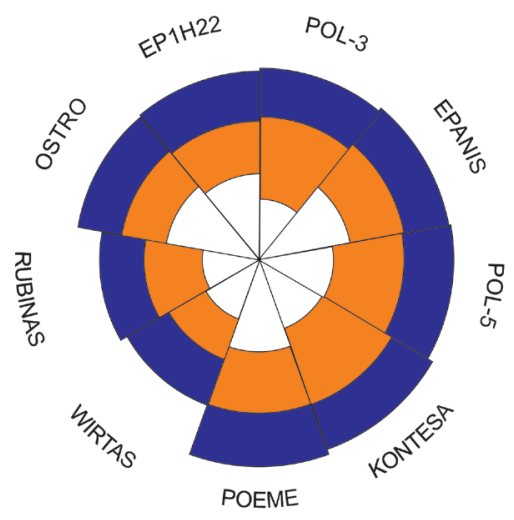

EP1H22). The remaining varieties were characterized by significantly thinner mechanical layers. In the region of the second internode, the mechanical layer was the thickest in winter spelt Poeme, and the thinnest in spelt Rubinas and Ostro (Table 2). The mechanical layer in the second internode was generally thinner than in the first internode, and the reported differences were statistically significant in both T. polonicum varieties and in winter spelt Poeme, EP1H22, and Ostro.

In all analyzed wheats, the average values of the section modulus were determined at 3.066 for the first internode and 3.606 for the second internode (the difference was significant at $\mathrm{p}<0.0063)$. Section modulus was similar for both internodes $(\mathrm{R}=0.879, \mathrm{p}=0.0018$ ) (Fig. 4), which points to similar responses to bending. It should be noted that both tested varieties of spring spelt were characterized by the lowest values of the section modulus (1.910 and

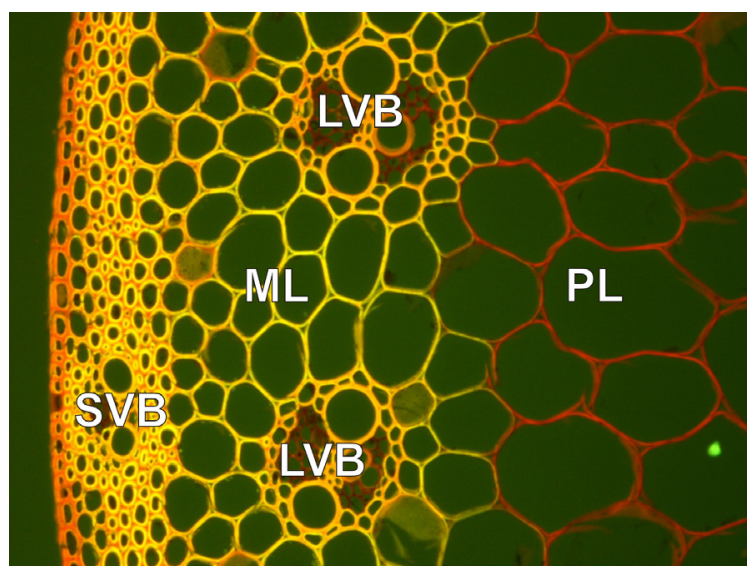

Fig. 3. Fragment of stem cross-section comprising the mechanical layer (cell walls that fluoresce yellow to green) and the parenchymal cell layer (red cell walls). ML - mechanical layer, PL - parenchymal layer, SVB - small vascular bundle, LVB large vascular bundle.

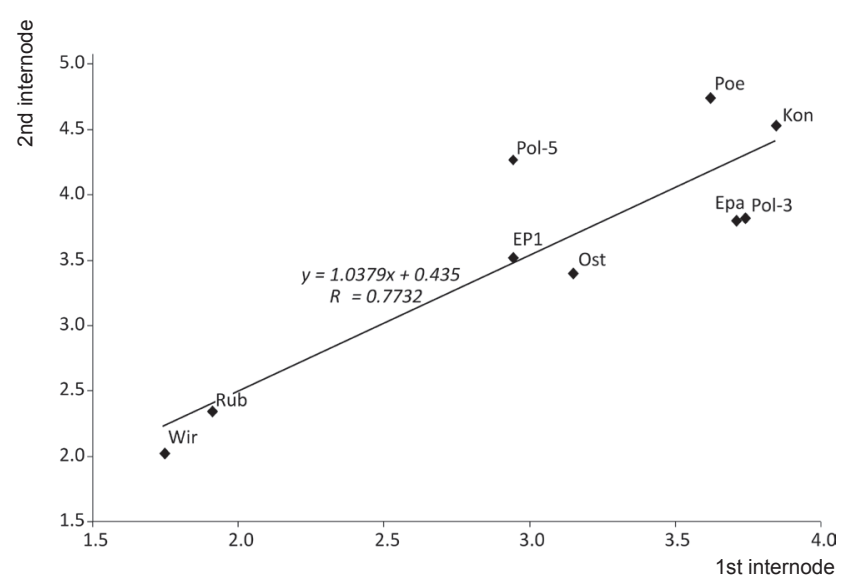

Fig. 4. Relationship between section modulus values for the first and second internode in all analyzed varieties (Wir - Wirtas, Rub - Rubinas, EP1 - EP1H22, Ost - Ostro, Epa - Epanis, Poe -

Poeme, Kon - Kontesa). in T. polonicum (Pol-3, Pol-5) and winter spelt (Poeme,
The evaluated wheats also differed in stem wall thick-
Theally significant only in Kontesa and Pol-3. ness (SWT) and mechanical layer thickness (MLT) (Fig. 2). The mechanical layer comprised cells that fluoresced yellow to green under the microscope. It consisted of a layer of small sclerenchymal cells, situated along the stem circumference, with strongly lignified walls and small vascular bundles, as well as a layer of large cells with large vascular bundles (Fig. 3).

The thickest stem walls in the region of the first internode were reported in Polish wheat Pol-5, and the thinnest cell walls - in spelt Wirtas, EP1H22, Ostro, and Epanis. In the region of the second internode, Pol-3 and Kontesa were characterized by the thickest stem walls, whereas Wirtas, Epanis, and Ostro - by the thinnest stem walls (Table 2). The stem walls in the second internode were generally thinner than in the first internode, and the observed differences were statistically significant in Pol-5, Rubinas, Epanis, Poeme, EP1H22, and Ostro (Table 2). The thick- 
1.746 for the first internode, and 2.345 and 2.023 for the second internode) in comparison with Kontesa, where the analyzed parameter was determined at 3.843 and 4.530, respectively. The above results suggest that both varieties could be significantly susceptible to lodging.

Common wheat Kontesa was characterized by the largest area of transverse section (ATS) in the first internode. The smallest ATS was noted in both spring varieties of spelt. In the second internode, the largest ATS was observed in winter spelt Poeme and common wheat Kontesa, and the smallest ATS - in both spring varieties of spelt (Table 2). ATS values were higher for the second internode than for the first internode, and the observed differences were statistically significant in Pol-5, Rubinas, Wirtas, Poeme, and $\mathrm{EP} 1 \mathrm{H} 22$.

The area of the stem wall (ASW) varied between the analyzed forms in both the first and second internode. The highest ASW values in the region of the first internode were reported in Pol-3, and the lowest - in Rubinas and

a

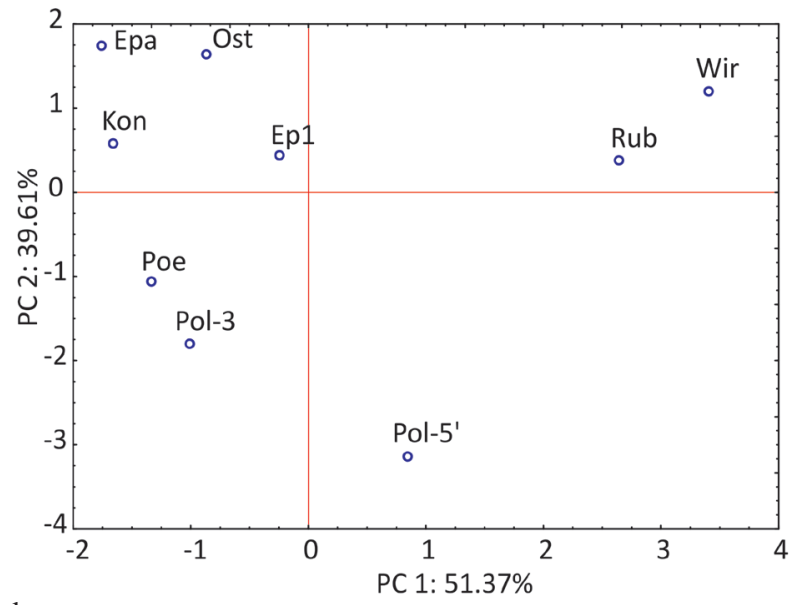

b

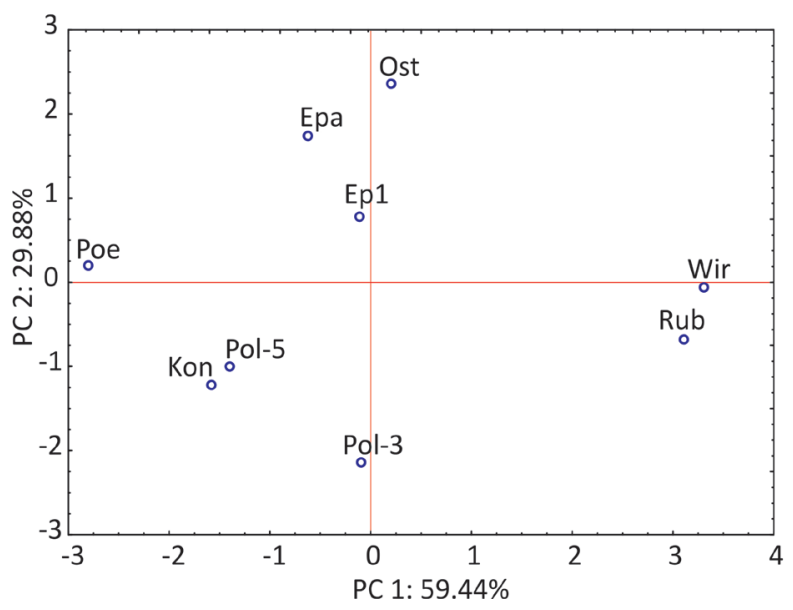

Fig. 5. Distribution of the varieties in the space of two principal components (PCs) for all analyzed traits; $\mathrm{a}-$ first, $\mathrm{b}$ - second internodes. Other explanations as in Fig. 4.
Wirtas. In the second internode, Kontesa, Pol-3, Pol-5, and Poeme were characterized by the highest ASW values, and Rubinas and Wirtas - by the lowest ASW values. In all analyzed wheats, the differences in ASW values of the first and second internode were not statistically significant (Table 2).

The evaluated anatomical traits were subjected to principal component analysis (PCA). The results point to significant similarities in the anatomy of the first and second internode between both spring spelt varieties (Fig. 5). PCA results for the first internode reveal considerable similarities between Kontesa and winter spelt varieties (Epanis, Ostro, and EP1H22). Those three winter varieties of spelt were also significantly similar in the anatomical traits of the second internode. PCA strongly discriminated the analyzed varieties: both PCs explained $90.98 \%$ (first internode) and $89.32 \%$ (second internode) of variance. Correlation coefficients for factors and variables, and the contribution of the variables to both PCs of the tested varieties are presented in Table 3.

The number of large vascular bundles in the second internode in the mechanical layer with lignified cell walls was analyzed (Fig. 3). The evaluated wheats were divided into five groups, and they were arranged in the following order (from the highest to the lowest number of vascular bundles in the cross-section): Poeme, Pol-5, Epanis, Pol-3,

T a b I e 3. Correlation coefficients for factors and variables, and the contribution of variables (in parentheses) for the analyzed Triticum genotypes

\begin{tabular}{|c|c|c|c|c|}
\hline \multirow{2}{*}{ Variable } & \multicolumn{2}{|c|}{ 1st internode } & \multicolumn{2}{|c|}{ 2nd internode } \\
\hline & PC 1 & PC 2 & PC 1 & PC 2 \\
\hline \multirow{2}{*}{ ID } & $-0.983 * * *$ & -0.151 & $-0.990 * * *$ & -0.017 \\
\hline & $(0.269)$ & $(0.008)$ & $(0.236)$ & $(<0.001)$ \\
\hline \multirow{2}{*}{ LD } & -0.557 & $0.815^{*}$ & -0.584 & $0.809 * *$ \\
\hline & $(0.086)$ & $(0.239)$ & $(0.082)$ & $(0.314)$ \\
\hline \multirow{2}{*}{ SWT } & 0.006 & $-0.936^{* *}$ & -0.564 & $-0.802 * *$ \\
\hline & $(<0.001)$ & $(0.316)$ & $(0.076)$ & $(0.307)$ \\
\hline \multirow{2}{*}{ MLT } & -0.409 & -0.645 & -0.532 & -0.238 \\
\hline & $(0.047)$ & $(0.150)$ & $(0.068)$ & $(0.027)$ \\
\hline \multirow{2}{*}{ ATS } & $-0.984 * * *$ & -0.131 & $-0.995 * * *$ & -0.033 \\
\hline & $(0.269)$ & $(0.006)$ & $(0.238)$ & $(0.001)$ \\
\hline \multirow{2}{*}{$\mathrm{AL}$} & -0.652 & 0.748 & -0.622 & $0.780^{*}$ \\
\hline & $(0.118)$ & $(0.202)$ & $(0.093)$ & $(0.291)$ \\
\hline \multirow{2}{*}{ ASW } & $-0.871 * *$ & -0.465 & $-0.929 * * *$ & -0.356 \\
\hline & $(0.211)$ & $(0.078)$ & $(0.207)$ & $(0.060)$ \\
\hline
\end{tabular}

$* \mathrm{p}<0.05, * * \mathrm{p}<0.01, * * * \mathrm{p}<0.001$. Other explanations as in Table 2. 


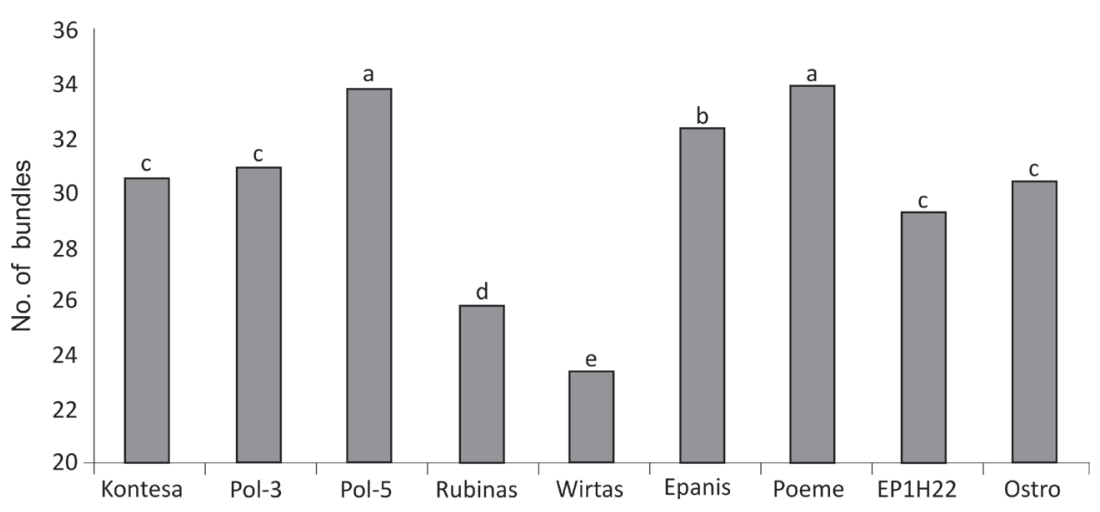

Fig. 6. The number of large vascular bundles in the second internode of the studied Triticum genotypes. a-e - mean values signed by the same letter do not differ significantly at $\mathrm{p}<0.05$ according to the SNK test.

Kontesa, Ostro, EP1H22, Rubinas, and Wirtas (Fig. 6). The average number of vascular bundles in Kontesa (30.50) was significantly higher than in Rubinas (25.78) and Wirtas (23.39), and significantly lower than in Pol-5 (33.83), Epanis (32.33), and Poeme (33.94).

\section{DISCUSSION}

Lodging of cereal plants poses a serious problem in agricultural production, and it has been analyzed extensively in numerous review articles (Berry et al., 2004; 2007; Pinthus, 1973). Buckling of lower internodes (stem lodging) is commonly observed in wheat, barley, and oats due to differences in the weight and strength of upper and lower internodes of the stem. In common wheat, traits that are most correlated with lodging resistance are: plant height, stem length, stem diameter, stem and spike weight, stem wall thickness, and mechanical layer thickness (Kelbert et al., 2004a,b; Kong et al., 2013; Wang et al., 2006; Zuber et al., 1999). Recent studies investigated the correlations between lodging resistance and the concentrations of cellulose, lignin, pectin, and protein in the stem (Kong et al., 2013; Wang et al., 2012). Strong correlations between plant height and lodging resistance were noted in modern cultivars of common wheat by Kelbert et al. (2004a,b), who studied the effects of artificially induced lodging on 13 and 25 genotypes of spring wheat, respectively.

In the 1970s, the interest in spelt was revived in Europe, mostly in Germany, Switzerland, and Belgium. The aim of recent breeding efforts is to reduce the height of spelt plants and improve their resistance to lodging. Similarly to common wheat, spelt is characterized by a very strong positive correlation between plant height and lodging resistance $(\mathrm{R}=0.65, \mathrm{p}<0.001)$ (Longin and Würschum, 2014). Although some success has been achieved in reducing plant height and improving lodging resistance, there is a general scarcity of published data about traits associated with susceptibility to lodging in $T$. spelta and T. polonicum (Konvalina et al., 2010; Sadowska et al., 2010, 2012). This study analyzed only the morphological and anatomical traits of two lower internodes in spelt and Polish wheat; nevertheless, it makes a valid contribution to filling the existing gap in knowledge. Our results cannot be extensively discussed due to the lack of comparative information in the literature.

In common wheat, resistance to lodging is highly correlated with plant height as well as stem diameter, stem wall thickness, mechanical layer thickness, and area of transverse section (Kelbert et al., 2004a; Kong et al., 2013; Wang et al., 2006; Zuber et al., 1999). Higher values of the above traits are indicative of increased resistance to lodging. In the group of the analyzed varieties, the largest diameter of the first and second internode was observed in common wheat Kontesa $(3.510 \mathrm{~mm})$ and winter spelt Poeme $(3.513 \mathrm{~mm})$, and the smallest - in spring spelt Wirtas and Rubinas (2.693 and $2.798 \mathrm{~mm}$, respectively). The second internode diameter was larger than the first internode diameter in all evaluated forms, which is a characteristic trait of common wheat and durum wheat (Kelbert et al., 2004a; Segit et al., 2005). The diameter of both internodes is larger in common wheat cultivars that are resistant to lodging than in sensitive varieties (Klebert et al., 2004a). This observation was validated by the values of the section modulus reported in this study, which indicate that Kontesa is most resistant and both spring spelt varieties are least resistant to lodging. The significant reduction in the first internode diameter in Polish wheat (Pol-5) and two winter spelt varieties (Poeme and EP1H22) could also contribute to their susceptibility to lodging.

Stem wall thickness, in particular wall thickness at the first three internodes (Wang et al., 2006; Żebrowski, 1992a), is an anatomical trait that is most highly correlated with resistance to lodging. Kelbert et al. (2004a) observed considerable differences in stem wall thickness in the second internode region between common wheat cultivars that are resistant and sensitive to lodging $(0.75 \mathrm{~mm}$ and $0.69 \mathrm{~mm}$, respectively). Similar results were reported in a study of four common wheat genotypes, where a positive correlation was noted between lodging resistance $v s$. stem wall thickness $(\mathrm{R}=0.972)$ and the weight of three lowest internodes ( $\mathrm{R}=0.986)$ (Kong et al., 2013). A trait that was particularly 
correlated with lodging resistance was mechanical layer thickness $(\mathrm{R}=1.000)$. According to Zuber et al. (1999), the most important traits of common wheat that should be taken into consideration in breeding resistant varieties are plant height, stem weight per cm of stem length, and stem diameter. Wang et al. (2006) observed that plants resistant to lodging are characterized by a larger stem diameter, thicker stem walls at the first internode, and a higher ratio of stem thickness to stem radius. According to Kong et al. (2013), wheat varieties with partially or completely solid stems are less susceptible to lodging. The varieties investigated in this study differed in the thickness of the lowest internodes and the mechanical layer, and stem wall thickness and mechanical layer thickness were greater in the first than in the second internode. The above traits were similar in both internodes only in common wheat Kontesa and spring spelt Wirtas.

According to some authors, the area of transverse section (ATS) of lower internodes is more correlated with lodging resistance than stem wall thickness (Żebrowski, 1992a). Kong et al. (2013) did not observe any correlations between lodging resistance and the area of transverse section in wheat. In our study, the highest ATS values in the region of the first and second internode were noted in common wheat Kontesa $\left(19.106 \mathrm{~mm}^{2}\right)$ and winter spelt Poeme $\left(19.274 \mathrm{~mm}^{2}\right)$, and the lowest ATS values - in spring spelt Wirtas $\left(11.335 \mathrm{~mm}^{2}\right)$ and Rubinas $\left(12.138 \mathrm{~mm}^{2}\right)$. Despite the above, the observed differences in ATS values at both internodes were not significant in any of the tested wheats. PCA results for all analyzed forms and traits confirm significant differences between the investigated wheats and, most importantly, strongly discriminate the tested wheat genotypes. The above finding suggests that shape descriptors of stem cross-sections should be analyzed in greater detail because they discriminate the analyzed varieties of three Triticum species more effectively than the analyses of separate variables. PCA results may prove to be highly useful for spelt breeders because selection for lodging resistance plays a particularly important role in T. spelta.

The correlations between lodging resistance and the number and size of vascular bundles in the stem cross-section have been investigated by numerous authors (Kelbert et al., 2004a; Kong et al., 2013; Wang et al., 2006; Zuber et al., 1999; Żebrowski, 1992a). The role played by vascular bundles in lodging resistance of wheat has not yet been fully explained. The presence of correlations between lodging resistance and the number of vascular bundles was suggested by earlier studies of wheat, triticale, and rye (Khanna, 1991). In wheat stems, vascular bundles are arranged in two rings: small bundles are distributed in the sclerenchymal layer, and large bundles - below the sclerenchymal layer. In a study of 15 wheat lines, Zuber et al. (1999) demonstrated minor variations in the number of large vascular bundles, which were determined at 30.1 on average (in the range of 26.1-33.0). The coefficient of correlation between the number of vascular bundles and lodging resistance evaluated on a 9-point scale was low and not statistically significant. Kelbert et al. (2004a) and Kong et al. (2013) did not observe any correlations between the number of vascular bundles and lodging resistance in common wheat. In a study of three wheat genotypes with different numbers of small and large vascular bundles, Wang et al. (2006) reported a positive correlation between the number of large vascular bundles per $\mathrm{mm}^{2}$ and bending resistance. In this study, the number of large vascular bundles differed between the analyzed varieties. The smallest number of vascular bundles was noted in spring spelt genotypes with the smallest internode diameter.

The present study analyzed plant traits that are correlated with lodging resistance in new and ancient wheats cultivated in Europe. Further work is needed to comprehensively assess the contribution of these traits to lodging resistance in different wheat varieties.

\section{CONCLUSIONS}

1. The analyzed wheat species differed significantly in the anatomical traits of two lower internodes and the number of large vascular bundles in the region of the second internode.

2. In all evaluated wheat genotypes, the values of the internode diameter, lumen diameter, area of transverse section, and area of lumen were higher at the second internode than at the first internode, whereas the reverse was reported in the values of stem wall thickness and mechanical layer thickness.

3. The results of principal component analysis and section modulus values for the first and second internode point to significant similarities between two studied spring spelt varieties, and between common wheat cultivar and two winter spelt varieties Epanis and Poeme.

4. The results of this study reveal both similarities and differences in traits associated with lodging resistance between ancient wheats and common wheat.

\section{REFERENCES}

Berry P.M., Sterling M., Spink J.H., Baker C.J., SylvesterBradley R., Mooney S.J., Tams A.R., and Ennos A.R., 2004. Understanding and reducing lodging in cereals. Advances Agronomy, 84, 217-271.

Berry P.M., Sylvester-Bradley R., and Berry S., 2007. Ideotype design for lodging-resistant wheat. Euphytica, 154, 165-179.

Cacak-Pietrzak G., Gondek E., and Jończyk K., 2013. Comparison of internal structure and milling properties of spelt and bread wheat from ecological farming (in Polish). Zesz. Probl. Post. Nauk Roln., 574, 3-10.

CCA 32nd complete edition, 2013. Official Journal of the EU, C 379A, 28 December 2013.

Gerlach D., 1972. Botanische Mikrotechnik. Eine Einführung (in Polish) PWRiL, Warszawa, Poland.

Kelbert A. J., Spaner D., Briggs K. G., and King J. R., 2004a. The association of culm anatomy with lodging susceptibility in modern spring wheat genotypes. Euphytica, 136, 211-221. 
Kelbert A.J., Spaner D., Briggs K. G., and King J. R., 2004b. Screening for lodging resistance in spring wheat breeding programmes. Plant Breeding, 123, 349-354.

Keller M., Karutz Ch., Schmid J. E., Stamp P., Winzeler M., Keller B., and Messmer M. M., 1999. Quantitative trait loci for lodging resistance in a segregating wheat $\times$ spelt population. Theoretical Applied Genetics, 98, 1171-1182.

Khanna V.K., 1991. Relationship of lodging resistance and yield to anatomical characters of stem in wheat, triticale and rye. Wheat Information Service, 73, 19-24.

Kong E., Liu D., Guo X., Yang W., Sun J., Li X., Zhan K., Cui D., Lin J., and Zhang A., 2013. Anatomical and chemical characteristics associated with lodging resistance in wheat. The Crop J., 1, 43-49.

Konvalina P., Stehno Z., Capouchová I, Zechner E., Berger S., Grausgruber H., Janovská D., Moudrý J.Sr. 2014. Differences in grain/straw ratio, protein content and yield in landraces and modern varieties of different wheat species under organic farming. Euphytica, 199, 31-40.

Konvalina P., Capouchova I., Stehno Z., and Moudry J., 2010. Morphological and biological characteristics of the land races of the spring soft wheat grown in the organic farming system. J. Central European Agric., 11(2), 235-244.

Koutroubas S.D., Fotiadis S., and Damalas C.A., 2012. Biomass and nitrogen accumulation and translocation in spelt (Triticum spelta) grown in Mediterranean area. Field Crops Res., 127, 1-8.

Longin C.F.H. and Würschum T., 2014. Genetic variability, heritability and correlation among agronomic and disease resistance traits in a diversity panel and elite breeding material of spelt wheat. Plant Breeding, 133(4), 459-464.

Milczarski P., 2008. Identification of QTLs of morphological traits related to lodging of rye (Secale cereale L.) (in Polish). Biuletyn IHAR, 250, 211-216.

Ookawa T., Yasuda K., Kato H., Sakai M., Seto M., Sunaga K.M., Motobayashi T., Tojo S., and Hirasawa T., 2010. Biomas production and lodging resistance in "Leaf Star", a new long-culm rice forage cultivar. Plant Production Sci., 13(1), 58-66.

Pinthus M.J., 1973. Lodging in wheat, barley and oats: the phenomenon, its causes and preventative measure. Advances Agronomy, 25, 209-263.

Rajput Er.R.K., 2012. Strength of Materials (Mechanics of Solids). SI Units. Chapter 5. Bending stresses in beams. S. Chand and Co. Ltd. Press, New Delhi, India.

Rasband W.S., ImageJ, U. S. National Institutes of Health, Bethesda, MD, USA, http://imagej.nih.gov/ij/, 1997-2014.

Rovenska B., 1973. Anatomical atlas of rye (in Czech). Academia NCAV, Praha, Czech Republic.

Ruebenbauer T., 1964. Plant Breeding (in Polish). PWRiL, Warszawa, Poland.

Ruebenbauer T. and Riegerowa H., 1955. Determination of the rigidity of winter wheat straw based on the mechanical properties of plants (in Polish). Acta Agrobotanica, 3, 45-73.

Sadowska U., Żabiński A., and Mudryk K., 2012. Lodging resistance of the selected varieties of spelt Triticum aestivum ssp. spelta L. (in Polish). Agric. Eng., 2(137), 269-278.

Sadowska U., Żabiński A., Mudryk K., and Pużyńska K., 2010. Some mechanical properties of stalks and ears of spelt (in Polish). Agric. Eng., 4(122), 189-197.

Segit Z., Kurzyp T., and Szwed-Urbaś K., 2005. Geometrical parameters and mechanical properties of stem of durum wheat (T. durum Desf.) (in Polish). Biuletyn IHAR, 235, 95-102.

StatSoft, Inc., 2011. STATISTICA (data analysis software system), version 10. www.statsoft.com.

Tyburski J. and Babalski M., 2006. Cultivation of spelt wheat. Guide for farmers (in Polish). Agricultural Advisory Centre in Brwinów, Branch Office in Radom, Poland.

Wang J., Zhu J., Huang R.Z., and Yang Y.S., 2012. Investigation of cell wall composition related to stem lodging resistance in wheat (Triticum aestivum L.) by FTIR spectroscopy. Plant Signaling Behavior, 7(7), 856-863.

Wang J., Zhu J., Lin Q., Li X., Teng N., Li Z., Li B., Zhang A., and Lin J., 2006. Effects of stem structure and cell wall components on bending strength in wheat. Chinese Sci. Bulletin, 51(7), 815-823.

Witzenberger A., Hack H., and van den Boom T., 1989. Erläuterungen zum BBCH-Dezimal-Code für die Entwicklungsstadien des Getraides - mit Abbildungen. Gesunde Pflanzen, 41, 384-388.

Wiwart M., Suchowilska E., Kandler W., Sulyok M., Groenwald P., and Krska R., 2013. Can Polish wheat (Triticum polonicum L.) be an interesting gene source for breeding wheat cultivars with increased resistance to Fusarium head blight? Genetic Resources Crop Evolution, 60, 2359-2373.

Zuber U., Winzeler H., Messmer M.M., Keller M., Keller B., Schmid J.E., and Stamp P., 1999. Morphological traits associated with lodging resistance of spring wheat (Triticum aestivum L.). J. Agronomy Crop Sci., 182, 17-24.

Żebrowski J., 1992a. Structural and mechanical determinants and methods of lodging resistance estimation in cereals. Part I. Morphological and anatomical traits of stem (in Polish). Biuletyn IHAR, 183, 73-82.

Żebrowski J., 1992b. Structural and mechanical determinants and methods of lodging resistance estimation in cereals. Part II. Mechanical properties of stem and root system traits (in Polish). Biuletyn IHAR, 183, 83-93. 